\title{
DEEP SEA CARIDEA (CRUSTACEA, DECAPODA) FROM CAMPOS BASIN, RJ, BRAZIL*
}

\author{
Irene A. Cardoso ${ }^{I} \&$ C. S. Serejo \\ Universidade Federal do Rio de Janeiro \\ Museu Nacional - Departamento de Invertebrados \\ (202940, Rio de Janeiro, RJ, Brasil) \\ ${ }^{1}$ Corresponding author: irenecardoso@mn.ufrj.br
}

\begin{abstract}
A B S T R A C T
During the Campos Basin Deep Sea Environmental Project coordinated by CENPES/PETROBRAS two collecting campaigns were performed. Both used the N/RB Astrogaroupa and fishery nets to collect samples from the continental slope in Campos Basin, RJ $\left(21^{\circ} 48^{\prime} \mathrm{S}\right.$ to $\left.22^{\circ} 48^{\prime} \mathrm{S}\right)$. Campaign Oceanprof I occurred in February, 2003 and collected 18 samples at depths between 1074 and 1649 m. Oceanprof II occurred in August, 2003 and collected 22 samples at depths between 1059 and $1640 \mathrm{~m}$. A total of 14 caridean species were collected: Parapontophilus sp. (Crangonidae); Glyphocrangon longirostris (Smith, 1882) (Glyphocrangonidae); Lebbeus sp. (Hippolytidae); Nematocarcinus ensifer (Smith, 1882) (Nematocarcinidae); Acanthephyra eximia Smith, 1884; A. quadrispinosa Kemp, 1939; A. stylorostratis (Bate, 1888); Janicella spinicauda (A. Milne Edwards, 1883); Meningodora vesca (Smith, 1887); Notostomus elegans A. Milne Edwards, 1881; Oplophorus spinosus (Brullé, 1839); and Systellaspis debilis (A. Milne Edwards, 1881) (Oplophoridae); Heterocarpus inopinatus Tavares, 1999 and Plesionika sp. (Pandalidae). Three out of these 14 species, Parapontophilus sp., Lebbeus sp. and Plesionika sp. are still under investigation and were not included in the present study. From the 11 species identified Nematocarcinus ensifer is a new record for the Brazilian continental slope.
\end{abstract}

\section{RESUMO}

Durante o Projeto de Caracterização Ambiental de Águas Profundas da Bacia de Campos coordenado pelo CENPES/PETROBRAS duas campanhas de coleta foram realizadas. Ambas utilizaram o N/RB Astrogaroupa e redes de pesca de arrasto com porta para coletar amostras do talude continental da Bacia de Campos, RJ $\left(21^{\circ} 48^{\prime} \mathrm{S}\right.$ a $\left.22^{\circ} 48^{\prime} \mathrm{S}\right)$. A campanha Oceanprof I ocorreu em fevereiro de 2003 , coletou 18 amostras em profundidades que variaram entre 1074 e $1649 \mathrm{~m}$ e a Oceanprof II em agosto de 2003 coletou 22 amostras em profundidades variando entre 1059 e $1640 \mathrm{~m}$. No total, 14 espécies de Caridea foram coletadas: Parapontophilus sp. (Crangonidae); Glyphocrangon longirostris (Smith, 1882) (Glyphocrangonidae); Lebbeus sp. (Hippolytidae); Nematocarcinus ensifer (Smith, 1882) (Nematocarcinidae); Acanthephyra eximia Smith, 1884; A. quadrispinosa Kemp, 1939; A. stylorostratis (Bate, 1888); Janicella spinicauda (A. Milne Edwards, 1883); Meningodora vesca (Smith, 1887); Notostomus elegans A. Milne Edwards, 1881; Oplophorus spinosus (Brullé, 1839); e Systellaspis debilis (A. Milne Edwards, 1881) (Oplophoridae); Heterocarpus inopinatus Tavares, 1999 e Plesionika sp. (Pandalidae). Dentre estas 14 espécies, Parapontophilus sp., Lebbeus sp. e Plesionika sp. estão sendo trabalhadas e não foram incluídas no presente trabalho. Das 11 espécies identificadas, Nematocarcinus ensifer representa uma nova ocorrência para o talude continental brasileiro.

Descriptors: Caridea; Deep Sea; Brazil.

Descritores: Caridea; mar profundo; Brasil.

\section{INTRODUCTION}

The Campos Basin is considered the largest oil reserve in the Brazilian continental shelf, covering an area of some $100,000 \mathrm{~km}^{2}$ extending from the State of Espirito Santo to the northern coast of Rio de Janeiro State.

(*) Paper presented at the $1^{\text {st }}$ Brazilian Congress of Marine Biology, on 15-19 May, 2006. Rio de Janeiro, Brazil.
In 1985, the country's first giant field called Albacora was discovered in water depths of more than $200 \mathrm{~m}$. Later, the giant Marlin and Barracuda fields were also discovered. Since then, Petrobras has been investing in deepwater exploration research and became the world leader in this kind of exploration. Around $65 \%$ of Petrobras area, offshore exploration blocks are in water depths over $400 \mathrm{~m}$. Consequently, in recent years the company has increased its exploration drilling activities in water more and more 
deeper. To maintain sustainable deepwater exploration, environmental knowledge and monitoring are required, and this study, part of Campos Basin Deep Sea Environmental Project, is a contribution to this major objective.

The Infraorder Caridea Dana, 1852, includes 36 families (Martin \& Davis, 2001). The Campos Basin Deep Sea Environmental Project collected 14 caridean species, representing six caridean families.

From the family Oplophoridae, eight species were collected: Acanthephyra eximia Smith, 1884; A. quadrispinosa Kemp, 1939; A. stylorostratis (Bate, 1888); Janicella spinicauda (A. Milne Edwards, 1883); Meningodora vesca (Smith, 1887); Notostomus elegans A. Milne Edwards, 1881; Oplophorus spinosus (Brullé, 1839) and Systellaspis debilis (A. Milne Edwards, 1881). These species were recently recorded in Brazilian waters by Cardoso \& Young (2005) and Cardoso (in press). Furthermore, other seven species of this family are recorded to Brazilian waters (Ramos-Porto \& Coelho, 1998; Tavares, 1999; Cardoso \& Young, 2005).

Only one species of the family Nematocarcinidae was collected and this is a new occurrence to Brazilian waters: Nematocarcinus ensifer (Smith, 1882). Previously, only one Nematocarcinidae species was recorded to Brazilian waters (Ramos-Porto \& Coelho, 1998).

Eight species of the family Glyphocrangonidae were previously recorded to Brazilian waters (Ramos-Porto \& Coelho, 1998; Komai, 2004) one of them, Glyphocrangon longirostris, collected by the Campos Basin Deep Sea Environmental Project: (Smith, 1882).

The family Pandalidae is represented in Brazilian waters by 9 species (Ramos-Porto \& Coelho, 1998; Tavares, 1999) among them Heterocarpus inopinatus Tavares, 1999 collected by the Campos Basin Deep Sea Environmental Project .

Three species, Parapontophilus sp. (Crangonidae), Plesionika sp. (Pandalidae) and Lebbeus sp. (Hippolytidae) are still under investigation and have not been included in the present work.

The carapace length was measured from rostrum base to the carapace end. The nomenclature of the mouth parts is that cited by McLaughlin (1980) and setae nomenclature is that proposed by Watling (1989) and Garm (2004).

\section{Material and Methods}

The samples analyzed herein were collected by N/RB Astrogaroupa as part of the Campos Basin Deep Sea Environmental Project coordinated by CENPES/PETROBRAS. This project intends to characterize the oceanic region of Campos Basin, at depths between 700 and $2000 \mathrm{~m}$, according to physical, chemical and biological properties of the water and the bottom. Two campaigns, Oceanprof I and II were performed: .Samples were collected using door nets in the continental slope of Campos Basin, RJ $\left(21^{\circ} 48^{\prime} \mathrm{S}\right.$ to $\left.22^{\circ} 48^{\prime} \mathrm{S}\right)$. Oceanprof I campaign occurred in February, 2003 and collected 18 samples at depths between 1074 and $1649 \mathrm{~m}$. Oceanprof II occurred in August, 2003 and collected 22 samples at depths between 1059 and $1640 \mathrm{~m}$.

The material collected was fixed in ethanol $70 \%$ and is stored in the collection of Museu Nacional, Rio de Janeiro (MNRJ).

\section{Systematics}

Family Glyphocrangonidae Smith, 1884

Glyphocrangon A. Milne Edwards, 1881

Glyphocrangon A. Milne Edwards, 1881: 3; Holthuis, 1971: 269.

Rhachocaris Smith, 1882: 41.

Glyptocrangon Norman, 1886: 8.

Thalascaris Bate, 1888: 282.

Plastocrangon Alcock, 1901: 125, 133.

Diagnosis: Body integument very firm. Rostrum well developed, dorsoventrally depressed, with two or three lateral teeth. Carapace with antennal and branchiostegal spines and a complicated array of grooves, carinae and tubercles that can include cervical groove, lateral groove, anterior groove, posteromarginal groove, lateromarginal groove, submedian carina, intermediate carina, antennal carina, lateral carina, sublateral carina, submarginal carina and marginal carina (modified from Holthuis, 1971).

$$
\text { Glyphocrangon longirostris (Smith, 1882) }
$$

Rhaocaris longirostris Smith, 1882: 51.

Glyphocrangon longirostris - Holthuis, 1971: 330; Crosnier \& Forest, 1973: 230; Komai, 2004: 35.

Material examined: Oceanprof I: A-6, $22^{\circ} 26^{\prime} \mathrm{S}$, $39^{\circ} 52^{\prime} \mathrm{W}, 1627 \mathrm{~m}, 1$ female, 1 male $(11,19 \mathrm{~mm})$, MNRJ 19229. Oceanprof II: A-15, $21^{\circ} 46^{\prime} \mathrm{S}, 39^{\circ} 48^{\prime} \mathrm{W}$, $1577 \mathrm{~m}, 1$ female $(20 \mathrm{~mm})$, MNRJ 20013.

Diagnosis: Rostrum shorter than carapace in adults, with two pairs of lateral spines. Carapace with cervical and lateral grooves; with anterior and posterior submedian carinae composed of tubercles; intermediate anterior carina with anterior tubercle spiniform; intermediate posterior carina composed of small tubercles; anterior antennal carina short; posterior antennal carina well developed; anterior lateral carina not expanded, not aligned with anterior antennal carina, with an anterior spine; anterior and posterior carinae well developed; branchiostegal and antennal spines present and strong. Stylocerite absent. Scaphocerite rounded, without distal tooth (modified from Komai, 2004). 
Distribution: Western Atlantic: from Massachusetts, U.S.A. to off the Brazilian coast (Espírito Santo and Rio de Janeiro). Eastern Atlantic: from Ireland to Cape Point, South Africa.

Remarks: Holthuis (1971) did a revision on all 12 Atlantic species of genus Glyphocrangon, presenting an identification key. Crosnier \& Forest (1973) studied two of these twelve species occurring in Eastern Atlantic. Recently, Komai (2004) worked with Western Atlantic (Brazilian) material and found eight of the 12 Atlantic species.

Glyphocrangon longirostris differs from the other eleven Atlantic species in the carapace with anterior lateral carina ending between antennal and branchiostegal spines, one tooth behind branchiostegal spine, anterior antennal carina absent and antennal spine on carapace margin (Fig. 1). The present material agrees with that previously described by Holthuis (1971), Crosnier \& Forest (1973) and Komai (2004) in all features above mentioned.

Nematocarcinidae Smith, 1884

Nematocarcinus A. Milne Edwards, 1881

Nematocarcinus A. Milne Edwards, 1881: 14; Crosnier \& Forest, 1973: 96; Chace, 1986: 68.

Eumiersia Smith, 1882: 77.

Stochasmus Bate, 1888: 822.

Diagnosis: Rostrum laterally depressed. Carapace smooth, not strongly sculptured. Mandible with palp, molar and incisor processes deeply separated. Pereopods 1-4 with epipods and exopods. Pereopods 3-5 unusually long, with carpus several times longer than propodus (modified from Chace, 1986).

\section{Nematocarcinus ensifer (Smith, 1882)}

Eumiersia ensifera Smith, 1882: 77.

Nematocarcinus ensiferus - Smith, 1884:368; 1886: 188; 1887: 665; Caullery, 1896: 377

Nematocarcinus ensifer - Sivertsen \& Holthuis, 1956: 19 (in part); Pequegnat, 1970: 75.

Material examined: Oceanprof I: A-8, $22^{\circ} 49^{\prime} \mathrm{S}$, $40^{\circ} 16^{\prime} \mathrm{W}, 1305 \mathrm{~m}, 1$ ovigerous female $(23 \mathrm{~mm})$, MNRJ 19179; A-12, $22^{\circ} 12^{\prime} \mathrm{S}, 39^{\circ} 47^{\prime} \mathrm{W}, 1640 \mathrm{~m}, 1$ ovigerous female, 1 male (27, $21 \mathrm{~mm})$, MNRJ 19176; A- $15,21^{\circ} 50^{\prime} \mathrm{S}, 39^{\circ} 47^{\prime} \mathrm{W}, 1649 \mathrm{~m}, 3$ ovigerous females (23-24 mm), MNRJ 19178. Oceanprof II: A-1, $22^{\circ} 41^{\prime} \mathrm{S}, 40^{\circ} 07^{\prime} \mathrm{W}, 1318 \mathrm{~m}, 4$ females, 2 juveniles $(11-$

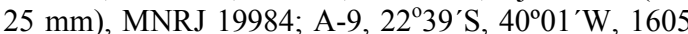
$\mathrm{m}, 1$ female $(25 \mathrm{~mm})$, MNRJ 19997; A-17, $22^{\circ} 15 \mathrm{~S}$, $39^{\circ} 51^{\prime} \mathrm{W}, 1332 \mathrm{~m}, 1$ female (22 mm), MNRJ 19988.
Diagnosis: Rostrum shorter than carapace in adults, dorsal margin armed until the tip, with more than 20 cuspidate setae, ventral margin unarmed. Carapace with suprabranchial, cervical and hepatic groove; branchiostegal and antennal spines present. Stylocerite with broad base and acute tip. Scaphocerite elongate, with distal tooth overreaching blade. Tergum of abdominal somite 4 with a rounded projection covering part of abdominal somite 5 (modified from Crosnier \& Forest, 1973).

Distribution: Western Atlantic: U.S.A. and Brazil (Rio de Janeiro). Eastern Atlantic: Portugal, Gulf of Gascogne, Azores, Morocco, Cape Verde.

Remarks: According to Crosnier \& Forest (1973) there are seven recognized species occurring in the Atlantic Ocean. Nematocarcinus ensifer differs from five of them in the rostrum ventral margin unarmed, dorsal margin armed with more than 20 cuspidate setae distributed until the tip (Fig. 2A) and telson not overreaching uropods. The closest species to $N$. ensifer is $N$. exilis that also presents the characters cited above. Nematocarcinus ensifer differs from $N$. exilis in the tergum of abdominal somite 4 with a rounded projection covering part of abdominal somite 5 .

The material herein examined agrees with Crosnier \& Forest (1973) description in all features cited on diagnosis (Fig. 2), but for the shape of the lateral margins of dorsal rounded projection in abdominal somite 4 that is more concave in North Atlantic (Albatross) material and more straight in South Atlantic, Brazilian material (Fig. 2E)

Oplophoridae Dana, 1852

Remarks: Until 2000 only four Oplophoridae species had been recorded in Brazilian waters (Ramos-Porto \& Coelho, 1998; Tavares, 1999). Recently, twelve species of Oplophoridae were recorded and truly described for the Brazilian coast (Cardoso \& Young, 2005; Cardoso, in press). Among these 15 species, eight have been recorded in the present study, which will be given a diagnosis and world distribution.

Acanthephyra A. Milne-Edwards, 1881

Ephyra Roux, 1831: 24.

Acanthephyra A. Milne-Edwards, 1881: 12; Chace, 1986: 6; Holthuis, 1993: 32; Cardoso \& Young, 2005: 7.

Bentheocaris Bate, 1888: 723.

Acanthephyropsis Riggio, 1895: 246. 

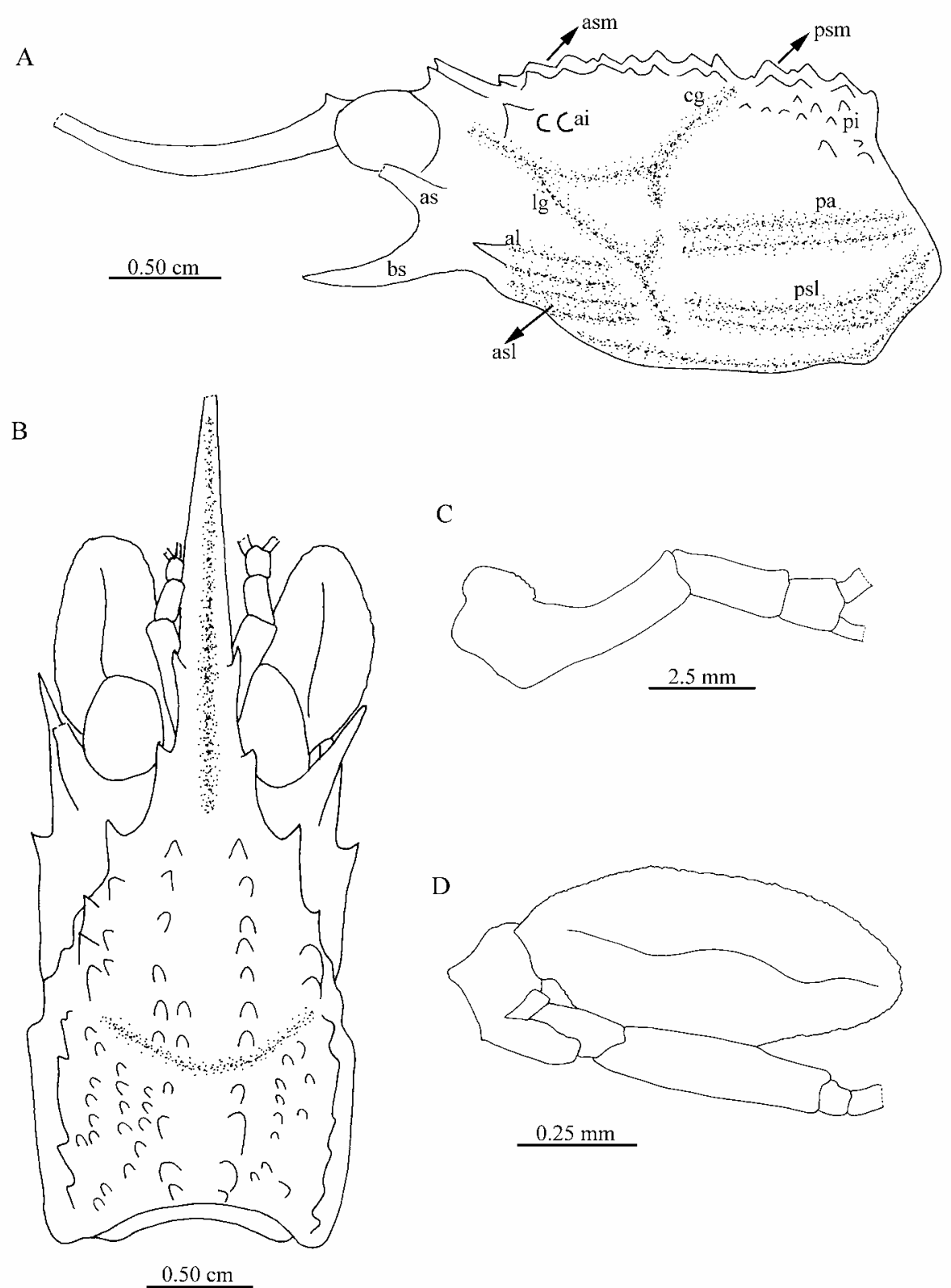

$\mathrm{C}$

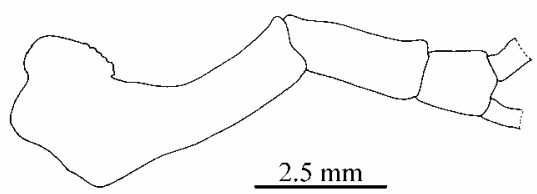

$\mathrm{D}$

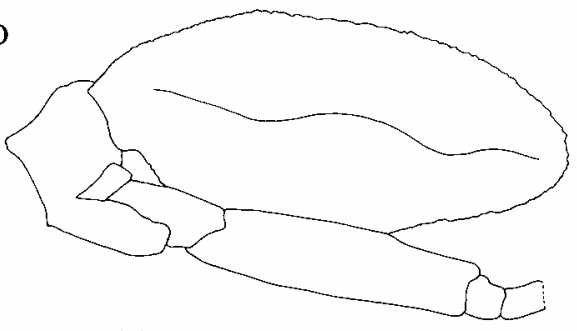

$0.25 \mathrm{~mm}$

Fig. 1. Glyphocrangon longirostris (Smith 1882), female (20mm), MNRJ 20013; (A) carapace lateral view; (B) carapace dorsal view; (C.) stylocerite, dorsal view; (D) scaphocerite, dorsal view. (as) antennal spine; (bs) branchiostegal spine; (cg)- cervical groove;( lg) lateral groove; carinae: (ai) - anterior intermediate; (al) anterior lateral;( asl) - anterior sublateral; (asm) anterior submedian;( pa) posterior antennal; (pi) posterior intermediate; $(\mathrm{psl})$ posterior sublateral; $(\mathrm{psm})$ posterior submedian. 


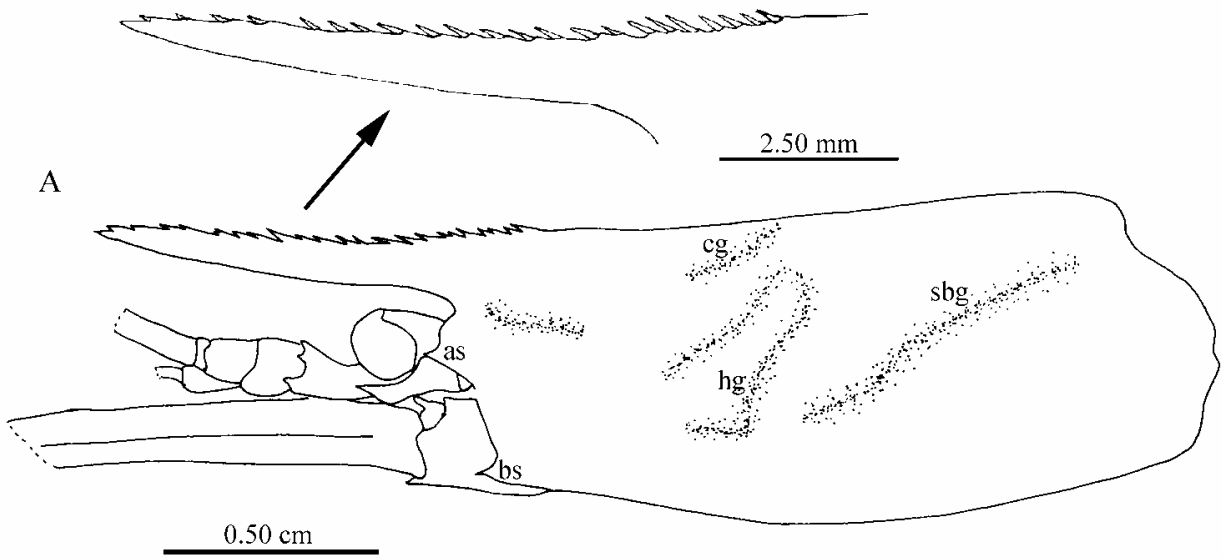

B

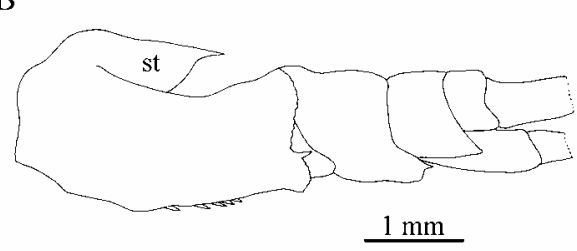

$\mathrm{C}$

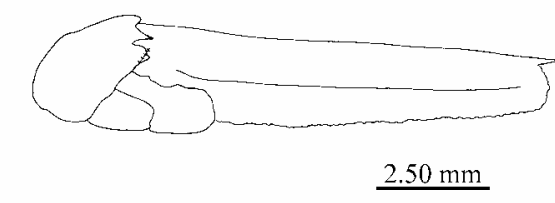

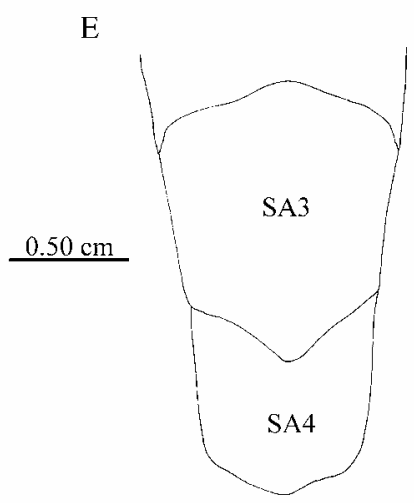

SA3

$\mathrm{D}$

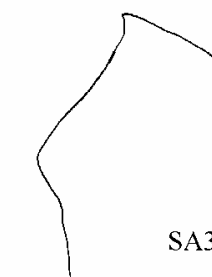

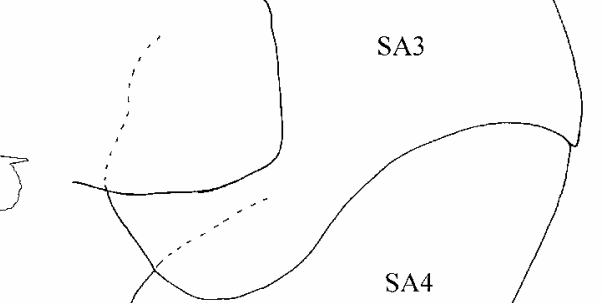

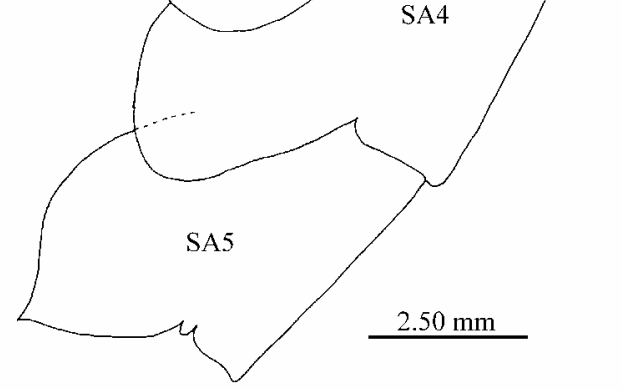

Fig. 2. Nematocarcinus ensifer (Smith, 1882), female (17mm), MNRJ 19984; (A) carapace lateral view; (B) stylocerite, dorsal view; (C) scaphocerite, dorsal view; ( D) abdominal somites 3-5, lateral view; (E) abdominal somites 3 and 4, dorsal view. (as) ntennal spine; (AS) abdominal somite; ( bs) branchiostegal spine; (cg) -ervical groove; (hg) hepatic groove; (sbg) -uprabranchial groove; (st ) stylocerite). 
Diagnosis: Rostrum with, at least, as many dorsal as ventral teeth. Carapace not pectinate dorsally; usually without lateral gastro-orbital carina. Abdomen dorsally carinate on, at least, somite 3 to 6 . Telson not tapering to sharply acute tip; without spinose end piece. Scaphocerite without lateral teeth. Mandible with incisor process armed in entire length. Pereopods with ischium and merus not broadly compressed. Pereopod 4 with epipod vestigial or absent. Appendix masculina on second pleopod. Eggs small to medium-sized and numerous (more than 80) (modified from Chace, 1986).

Acanthephyra eximia Smith, 1884

Acanthephyra eximia Smith, 1884: 376; 1886: 63. Acanthephyra angusta Bate, 1888: 737.

Acanthephyra edwardsii Bate, 1888: 747; Moreira, 1901: 10.

Acanthephyra brachytelsonis Bate, 1888: 753.

Acanthephyra eximia - Crosnier \& Forest, 1973: 34; Chace, 1986: 18; Ramos-Porto \& Coelho, 1998: 326; Tavares, 1999: 675; Cardoso \& Young, 2005: 14.

Material examined: Oceanprof II: A-3, 22 $32^{\prime} \mathrm{S}$, $39^{\circ} 56^{\prime} \mathrm{W}, 1600 \mathrm{~m}, 1$ male $(18 \mathrm{~mm})$, MNRJ 19994; A$13,21^{\circ} 53^{\prime} \mathrm{S}, 39^{\circ} 53^{\prime} \mathrm{W}, 1060 \mathrm{~m}, 2$ males $(35,36 \mathrm{~mm})$, MNRJ 19983.

Diagnosis: Carapace with rostrum overreaching scaphocerite, ventral margin with three, occasionally four teeth; antennal spine present; branchiostegal spine present, without distinct carina. Abdomen dorsally carinate on all somite but somite 1 ; somites 1 to 4 with posteromesial tooth, the one of somite 3 distinctly strong. Male pleopod 1 with endopod, rounded, with numerous stout setae on proximal to mesial portion, distal lobe with numerous hook setae; male pleopod 2 with appendix interna, slightly half the length of appendix masculina, with densely plumose setae on lateral margins and slightly triangular shape on distal portion; appendix masculina with pectinate setae on distal and lateral margins (modified from Chace, 1986).

Distribution: Western Atlantic: from Cape Hatteras to Bahamas, Gulf of Mexico, Brazil (Sergipe to Rio de Janeiro). Eastern and Central Atlantic: France (Gulf of Gascogne), Spain (Bay of Cadix), near Gibraltar, Azores, Madeira and Canary Archipelagos. Indian and Pacific: from Southeastern Africa to Japan, Hawaii and New Zealand.

$$
\text { Acanthephyra quadrispinosa Kemp, } 1939
$$

Acanthephyra batei - Stebbing, 1905: 107 (not A. batei Faxon, 1895).
Acanthephyra quadrispinosa Kemp, 1939: 576; Barnard, 1950: 668; Chace, 1986: 26; Kensley, 1987: 284; Cardoso \& Young, 2005: 21.

Material examined: Oceanprof I: A-8, $22^{\circ} 48^{\prime} \mathrm{S}$, $40^{\circ} 15^{\prime} \mathrm{W}, 1324 \mathrm{~m}, 1$ male $(14 \mathrm{~mm})$, MNRJ 19195. Oceanprof II: A-9, $22^{\circ} 39^{\prime} \mathrm{S}, 40^{\circ} 01^{\prime} \mathrm{W}, 1600 \mathrm{~m}, 1$ female (9 mm), MNRJ 19998.

Diagnosis: Carapace with rostrum overreaching scaphocerite, ventral margin with three to seven teeth; antennal spine present; branchiostegal spine present with distinct carina extending twice the length of spine. Abdomen dorsally carinate on all somites, except on somite 1; somites 3 to 6 with posteromesial tooth, the one of somite 3 distinctly strong. Telson sulcate on dorsal midline, with four pairs of dorsolateral stout setae (modified from Chace, 1986).

Distribution: South Atlantic Ocean: from $35^{\circ} \mathrm{S}$ to $40^{\circ} \mathrm{S}$; Brazil (Espírito Santo and Rio de Janeiro). Indian and Pacific Oceans: from East Africa to $163^{\circ} \mathrm{W}$, and from $25^{\circ} \mathrm{N}$ to $44^{\circ} \mathrm{S}$.

\section{Acanthephyra stylorostratis (Bate, 1888)}

Bentheocaris stylorostratis Bate, 1888: 726.

Acanthephyra stylorostratis - Calman, 1925: 14; Chace, 1936: 30; 1940: 144; 1986: 10; Cardoso \& Young, 2005: 27.

Material examined: Oceanprof II: A-12, $22^{\circ} 12^{\prime} \mathrm{S}$, $39^{\circ} 47^{\prime} \mathrm{W}, 1640 \mathrm{~m}$, 1 female (12 mm), MNRJ 19987.

Diagnosis: Carapace with a thin crest that projects into a rounded rostrum with six spiniform teeth dorsally, anterior one styliform and longer than others; antennal spine small; branchiostegal spine supported by a long carina, reaching $2 / 3$ of carapace. Abdomen dorsally carinate on all somites, except on somite 1 ; somites 3 to 6 with posteromesial tooth; the one of somite 3 distinctly strong. Male pleopod 1, endopod rounded, with numerous long, stout setae on anterior margin, and a distal lobe with hook setae. Male pleopod 2, appendix interna $1 \frac{1}{4}$ length of appendix masculina, apex triangular with hook setae; appendix masculina with rounded tip, simple setae on distal margin (Cardoso \& Young, 2005).

Distribution: Western Atlantic: U.S.A. (off New Jersey), Mexico (Gulf of Mexico), Brazil (Rio de Janeiro). Eastern Atlantic: Canary, Madeira and Cape Verde Islands. Indian and Pacific: South Africa (Natal), Tuamotu Archipelago.

\section{Janicella Chace, 1986}

Janicella Chace, 1986: 43; Holthuis, 1993: 36; Cardoso \& Young, 2005: 39. 
Diagnosis: Rostrum with more dorsal than ventral teeth. Carapace not pectinate dorsally; without lateral gastro-orbital carina; branchiostegal groove present, not delimited by vertical groove. Abdomen dorsally carinate on somites 2 to 4 ; dorsal tooth on somites 3 to 6 , the one of somite 2 distinctly strong; somite 6 longer than 5 . Telson tapering to sharply acute tip; with spinose end piece. Scaphocerite with lateral teeth. Mandible with incisor process armed along entire length, molar process reduced. Pereopods with ischium and merus not broadly compressed. Pereopod 4 with epipod well developed except for the vertical component. Appendix masculina absent on second pleopod. A few, nine or ten, large eggs (modified from Chace, 1986).

Janicella spinicauda (A. Milne Edwards, 1883)

Oplophorus spinicauda A. Milne Edwards, 1883; Chace, 1940: 184; Kensley, 1972: 38.

Oplophorus foliaceus Rathbun, 1906: 922; De Man, 1920: 48.

Acathephyra anomala Boone, 1927: 104.

Janicella spinicauda - Chace, 1986: 44; Kensley, 1987: 285; Cardoso \& Young, 2005: 39.

Material examined: Oceanprof I: A-18, $22^{\circ} 15^{\prime} \mathrm{S}$, $39^{\circ} 47^{\prime} \mathrm{W}, 1608 \mathrm{~m}, 1$ ovigerous female $(11 \mathrm{~mm}), 2$ females $(4.5,10.5 \mathrm{~mm}), 3$ males $(7.5$ to $11 \mathrm{~mm})$, MNRJ 19047; A-1, $22^{\circ} 24$ 'S, $39^{\circ} 54^{\prime} \mathrm{W}, 1128 \mathrm{~m}, 2$ females $(6,9 \mathrm{~mm})$, MNRJ 19048; A-12, $22^{\circ} 11$ 'S $39^{\circ} 47^{\prime} \mathrm{W}, 1632 \mathrm{~m}, 2$ females $(7.5,8 \mathrm{~mm})$, MNRJ $19180 ; 22^{\circ} 15$ 'S, A- $17,39^{\circ} 51^{\prime} \mathrm{W}, 1294 \mathrm{~m}, 31$ ovigerous females ( 8.5 to $11 \mathrm{~mm}), 15$ female ( 7 to $10.5 \mathrm{~mm}), 20$ males $(8$ to $11 \mathrm{~mm})$, MNRJ 19181; A- $10,22^{\circ} 11^{\prime} \mathrm{S}$, $39^{\circ} 51^{\prime} \mathrm{W}, 1144 \mathrm{~m}, 3$ females $(4$ to $7 \mathrm{~mm}$ ), 4 males (7$11 \mathrm{~mm}$ ), MNRJ 19182; A-4, 22 $244^{\circ} \mathrm{S}, 39^{\circ} 54^{\prime} \mathrm{W}$, $1128 \mathrm{~m}, 3$ ovigerous females (10 to $10.5 \mathrm{~mm}), 5$ females ( 7.5 to $9.5 \mathrm{~mm}$ ), 4 males ( 9 to $11 \mathrm{~mm}$ ), MNRJ 19183; A-5, $22^{\circ} 27^{\prime} \mathrm{S}, 39^{\circ} 54^{\prime} \mathrm{W}, 1320 \mathrm{~m}, 3$ females (8 to $11 \mathrm{~mm})$, MNRJ 19194; A-2, 22 $24^{\prime} \mathrm{S}, 39^{\circ} 55^{\prime} \mathrm{W}, 1130 \mathrm{~m}$, 1 female $(8.5 \mathrm{~mm})$, MNRJ 19213; A-7, $22^{\circ} 45^{\prime} \mathrm{S}$, $40^{\circ} 19^{\prime} \mathrm{W}, 1124 \mathrm{~m}, 3$ females $(6.5$ to $7 \mathrm{~mm}), 3$ males (5.5 to $7 \mathrm{~mm}$ ), MNRJ 19214; A-14, $21^{\circ} 50^{\prime} \mathrm{S}, 39^{\circ} 49^{\prime} \mathrm{W}$, $1358 \mathrm{~m}, 1$ male $(9 \mathrm{~mm})$, MNRJ 19215; A-11, $22^{\circ} 10^{\prime} \mathrm{S}$, $39^{\circ} 48^{\prime} \mathrm{W}, 1319 \mathrm{~m}, 3$ males (9 to $10 \mathrm{~mm}$ ), MNRJ 19216; A- $18,22^{\circ} 15^{\prime} \mathrm{S}, 39^{\circ} 47^{\prime} \mathrm{W}, 1608 \mathrm{~m}, 1$ ovigerous female $(9.5 \mathrm{~mm}), 2$ females $(7,7.5 \mathrm{~mm}), 1$ male (10.5mm), MNRJ 19218; A-6, 22 ${ }^{\circ} 27^{\prime} \mathrm{S}, 39^{\circ} 52^{\prime} \mathrm{W}, 1649$ $\mathrm{m}, 1$ female $(8 \mathrm{~mm})$, MNRJ 19219; A-16, $22^{\circ} 15^{\prime} \mathrm{S}$, $39^{\circ} 53^{\prime} \mathrm{W}, 1071 \mathrm{~m}, 1$ male $(7 \mathrm{~mm})$, MNRJ 19224. Oceanprof II: A-2, $22^{\circ} 30^{\prime} \mathrm{S}, 40^{\circ} 00^{\prime} \mathrm{W}, 1107 \mathrm{~m}, 1$ male (11mm), MNRJ 19999; A-11, $22^{\circ} 11^{\prime} \mathrm{S}, 39^{\circ} 49^{\prime} \mathrm{W}$, 1332m, 4 females $(8-11 \mathrm{~mm})$, MNRJ 19991; A-17, $22^{\circ} 16^{\prime} \mathrm{S}, 39^{\circ} 51^{\prime} \mathrm{W}, 1332 \mathrm{~m}, 1 \mathrm{male}(8 \mathrm{~mm})$, MNRJ 19986.
Diagnosis: Carapace with rostrum overreaching scaphocerite, ventral margin with six teeth, dorsal margin with 12 teeth; antennal spine absent; branchiostegal spine not well marked, without distinct carina. Scaphocerite with four teeth on mesial outer margin. Abdomen dorsally carinate on somites 2 to 4 , with strong posteromesial tooth, the one of somite 2 distinctly strong; somites 1 and 2 with pleura ventral margin convexly incised in male. Male pleopod 1, endopod leaf like, densely plumose, articulated setae on lateral margins, several pectinate setae on outer surface, several hook setae on tip; male pleopod 2 without appendix masculina; appendix interna with densely plumose setae on lateral margins, rounded tip with several hook setae (modified from Chace, 1986).

Distribution: Western Atlantic: U.S.A. (east coast of Florida), Bermuda, Bahamas, Caribbean Sea, Honduras, Brazil (Bahia to Rio de Janeiro). Indian and Pacific Oceans: north of Madagascar, southwestern India, Philippines, Hawaii.

Meningodora Smith, 1882

Meningodora Smith, 1882: 73; Crosnier \& Forest, 1973: 43; Chace, 1986: 48.

Diagnosis: Rostrum with more dorsal than ventral teeth. Carapace not denticulate dorsally; with lateral gastro-orbital carina. Abdomen dorsally carinate on, at least, somite 3 to 6 . Telson not tapering to sharply acute tip; without spinose end piece. Scaphocerite without lateral teeth. Mandible with incisor process armed in half length. Pereopods with ischium and merus not broadly compressed. Pereopod 4 with epipod vestigial. Appendix masculina on second pleopod. Eggs small to medium-sized and numerous (more than 80) (modified from Chace ,1986).

Meningodora vesca (Smith, 1887)

Notostomus viscus Smith, 1886: 189 (nomen nudum). Notostomus vescus - Smith, 1887:676; De Man, 1920: 46; Chace, 1936: 28; 1940: 153; 1947: 21.

Acanthephyra brevirostris Bate, 1888: 751 (not Smith, 1884).

Acanthephyra batei Faxon, 1895: 167.

Acanthephyra Batei - Kemp, 1906: 22; De Man, 1920: 41.

Notostomus Batei - Balss, 1925: 267.

Meningodora vesca - Crosnier \& Forest, 1968: 1130; 1973:46; Chace, 1986: 50; Cardoso, in press.

Material examined: Oceanprof II: A-13, 21 ${ }^{\circ} 53^{\prime} 14^{\prime \prime}$, $39^{\circ} 51^{\prime} 43^{\prime \prime} \mathrm{W}, 1064 \mathrm{~m}, 1$ female $(15.5 \mathrm{~mm})$, MNRJ 19450. 
Diagnosis: Carapace with rostrum short, reaching a half of scaphocerite length, ventral margin with two teeth; antennal spine present; branchiostegal spine present, well developed without distinct carina. Abdomen dorsally carinate on somites 3 to 6; abdominal somites 4 to 6 with posteromesial tooth. Female pleopod 1 with endopod leaf like, anterior margin with simple setae, posterior margin with plumose articulated setae. Female pleopod 2 appendix interna with numerous plumose setae on lateral margins, distal portion with hook setae.

Distribution: Western Atlantic: Bermudas, Bahamas, Brazil (Rio de Janeiro). Eastern Atlantic: Portugal, Azores Island, Canaries Island, Gabon, Angola. Indian and Pacific: Bay of Bengal, Philippines, Indonesia.

Notostomus A. Milne Edwards, 1881

Notostomus A. Milne Edwards, 1881: 7; Chace, 1986: 52; Holthuis, 1993: 38; Cardoso \& Young, 2005: 46.

Diagnosis: Rostrum with more dorsal than ventral teeth. Carapace denticulate dorsally; with lateral gastro-orbital carina; with two, or more longitudinal carina near ventral margin; branchiostegal groove present, delimited by vertical groove. Abdominal somites 3 to 5 with strong dorsal tooth; somite 6 shorter than 5, without dorsal carina. Telson tapering to sharply acute tip; without spinose end piece. Scaphocerite with lateral teeth. Mandible with incisor process armed in half length. Pereopods with ischium and merus not broadly compressed. Pereopod 4 with epipod vestigial. Appendix masculina present on second pleopod. Eggs small and numerous, more than 80, (modified from Chace, 1986).

Notostomus elegans A. Milne Edwards, 1881

Notostomus elegans A. Milne Edwards, 1881: 7; Crosnier \& Forest, 1973: 49; Chace, 1986: 56; Kensley, 1987: 287; Cardoso \& Young, 2005: 46.

Notostomus patentissimus Bate, 1888: 826.

Notostomus longirostris Bate, 1888: 833.

Notostomus westergreni Faxon, 1893: 208.

Notostomus atlanticus Lenz \& Strunck, 1914: 330; De Man, 1920: 46.

Material examined: Oceanprof I: A-12, $22^{\circ} 11^{\prime} \mathrm{S}$, $39^{\circ} 47^{\prime} \mathrm{W}, 1632 \mathrm{~m}, 1$ female (20.5 mm), MNRJ 19156.

Diagnosis: Carapace with rostrum overreaching scaphocerite length, with about 14 ventral teeth; antennal spine present; branchiostegal spine present, with distinct carina that extends to posterior carapace margin. Abdomen dorsally carinate on all somites; somites 3 to 6 with posteromesial tooth, the one of somite 3 distinctly strong. Female pleopod 1 with endopod leaf shaped, numerous plumose, articulated setae on lateral margin; female pleopod 2 with appendix interna, plumose setae on lateral margins, hook setae on rounded tip (modified from Chace, 1986).

Distribution: Western Atlantic: Bermudas, Bahamas, Gulf of Mexico, Brazil (Espírito Santo and Rio de Janeiro). Eastern Atlantic: Portugal, Spain (Bay of Cadix), Açores Archipelago, south Africa. Indian and Pacific Oceans: Philippines, Indonesia, Australian east coast, Ecuador.

Oplophorus H. Milne Edwards, 1837

Oplophorus H. Milne Edwards, 1837: 423; Chace, 1986: 57; Holthuis, 1993: 39; Cardoso \& Young, 2005: 52.

Diagnosis: Rostrum with as many or more dorsal ventral teeth. Carapace not denticulate dorsally; without lateral gastro-orbital carina; branchiostegal groove present, not delimited by vertical groove. Abdomen somite 3 to 5 with strong dorsal tooth; somite 6 shorter than 5 , without dorsal carina. Telson tapering to sharply acute tip; with or without spinose end piece. Scaphocerite with lateral teeth (except in $O$. novazeelandiae). Mandible with incisor process in entire length. Pereopods with ischium and merus not broadly compressed. Pereopod 4 with epipod well developed, except for vertical component. Appendix masculina present on second pleopod. A few, less than 50, large eggs (modified from Chace, 1986).

Oplophorus spinosus (Brullé, 1839)

Palaemon spinosus Brullé, 1839: 18.

Oplophorus grimaldii Coutiére, 1905: 1; Chace, 1940: 187; Kensley, 1972: 38.

Oplophorus spinosus - Holthuis, 1949: 229; Crosnier \& Forest, 1973: 25; Chace, 1986: 59; Kensley, 1987: 289; Cardoso \& Young, 2005: 58.

Material examined: Oceanprof I: A-12, $22^{\circ} 11$ 'S, $39^{\circ} 47^{\prime} \mathrm{W}, 1632 \mathrm{~m}, 1 \mathrm{male}(15.5 \mathrm{~mm})$, MNRJ 19184; A-7, $22^{\circ} 45^{\prime} \mathrm{S}, 40^{\circ} 19^{\prime} \mathrm{W}, 1124 \mathrm{~m}, 3$ females (8 to 10 $\mathrm{mm}), 3$ males (11 to $13 \mathrm{~mm}$ ), MNRJ 19186; A-4, $22^{\circ} 24^{\prime} \mathrm{S}, 39^{\circ} 54^{\prime} \mathrm{W}, 1128 \mathrm{~m}, 1$ ovigerous female (17 $\mathrm{mm})$, MNRJ 19187; A-2, 30'S, 4000'W, $1122 \mathrm{~m}, 1$ male (14 mm), MNRJ 19193; A-6, $22^{\circ} 27^{\prime} \mathrm{S}, 39^{\circ} 52^{\prime} \mathrm{W}$, $1649 \mathrm{~m}, 1$ female (13 mm), MNRJ 19217; A-9, $22^{\circ} 41^{\prime} \mathrm{S}, 40^{\circ} 02^{\prime} \mathrm{W}, 1609 \mathrm{~m}, 3$ females (13.5 to $19 \mathrm{~mm}$ ), MNRJ 19188; A-18, $22^{\circ} 15^{\prime} \mathrm{S}, 39^{\circ} 47^{\prime \prime} \mathrm{W}, 1608 \mathrm{~m}, 1$ female $(12 \mathrm{~mm}), 2$ males $(16,17.5 \mathrm{~mm})$, MNRJ 19190; A-1, $22^{\circ} 45^{\prime} \mathrm{S}, 40^{\circ} 10^{\prime} \mathrm{W}, 1322 \mathrm{~m}, 6$ females $(8.5$ to $12.5 \mathrm{~mm}$ ), 4 males (13 to $18 \mathrm{~mm}$ ), MNRJ 19185; A- 
$16,22^{\circ} 15^{\prime} \mathrm{S}, 39^{\circ} 53^{\prime} \mathrm{W}, 1071 \mathrm{~m}, 2$ males $(16.5,19 \mathrm{~mm})$, MNRJ 19189. Oceanprof II: A-1, $22^{\circ} 41^{\prime} \mathrm{S}, 40^{\circ} 07^{\prime} \mathrm{W}$, $1318 \mathrm{~m}, 1$ ovigerous female, 1 male $(20,10 \mathrm{~mm})$, MNRJ 19992; A-3, 22 $32^{\circ} \mathrm{S}, 39^{\circ} 56^{\prime} \mathrm{W}, 1605 \mathrm{~m}, 1$ ovigerous female (13 mm), MNRJ 19985; A-11, $22^{\circ} 11^{\prime} \mathrm{S}, 39^{\circ} 49^{\prime} \mathrm{W}, 1332 \mathrm{~m}, 2$ ovigerous females $(9,11$ $\mathrm{mm})$, MNRJ 19990.

Diagnosis: Carapace with rostrum overreaching scaphocerite, ventral margin with seven teeth; antennal spine present; branchiostegal spine present, without distinct carina; without sharp tooth near posterior end of ventral margin; with posterior extensions of upper lateral rostral carina slightly convergent in dorsal aspect. Scaphocerite with 11 teeth on outer margin, and a barb near tip of inner margin. Abdomen not dorsally carinate on somite 6 ; pleura of somite 1 without small tooth on ventral margin; somites 3 to 5 with posteromesial tooth, the one of somite 3 distinctly strong. Male pleopod 1 with endopod rounded, densely plumose setae on lateral margins, hook setae on tip; male pleopod 2, appendix masculina slender with strong pectinate setae on tip; appendix interna half length of appendix masculina, lateral margins with pappose setae, distal portion rounded and with numerous hook setae (Cardoso \& Young, 2005).

Distribution: Western Atlantic: U.S.A., Bermudas, Bahamas, Brazil (Bahia, Espírito Santo and Rio de Janeiro). Eastern Atlantic: Azores, Madeira and Canary Archipelagos, Senegal, Tristan da Cunha. Indian and Pacific: southwestern Indian Ocean, west Australia, Indonesia, south Japan, Hawaii.

Systellaspis Bate, 1888

Systellaspis Bate, 1888: 757; Chace, 1986: 61; Holthuis, 1993: 39; Cardoso \& Young, 2005: 64.

Hoplopasiphaea Yokoya \& Shibata, 1965: 4.

Diagnosis: Rostrum with more dorsal than ventral teeth. Carapace not carinate or denticulate dorsally; with or without lateral gastro-orbital carina; without branchiostegal groove. Abdomen not dorsally carinate on all somites; somite 6 longer than somite 5 . Telson tapering to sharply acute tip; with spinose end piece. Scaphocerite without lateral teeth. Mandible with incisor process armed in entire length. Pereopods with ischium and merus not broadly compressed. Pereopod 4 with epipod well developed, except for vertical component. Appendix masculina present on second pleopod. Eggs large and a few, less than 50 (modified from Chace 1986).

Systellaspis debilis (A. Milne-Edwards, 1881) Acanthephyra debilis A. Milne-Edwards, 1881: 13.
Miersia gracilis Smith, 1882: 70.

Systellaspis Bouvieri Coutiére, 1905: 8.

Systellaspis debilis - Crosnier \& Forest, 1973: 87; Chace, 1940: 181; 1986: 67; Cardoso \& Young, 2005: 64.

Material examined: Oceanprof I: A-8, $22^{\circ} 48^{\prime} \mathrm{S}, 40^{\circ} 15^{\prime}$, $1324 \mathrm{~m}, 1$ female $(13 \mathrm{~mm})$, MNRJ 19221; A-9, $22^{\circ} 41^{\prime} \mathrm{S}, 40^{\circ} 02^{\prime} \mathrm{W}, 1609 \mathrm{~m}, 1$ male $(13.5 \mathrm{~mm})$, MNRJ 19222. Oceanprof II: A-12, $22^{\circ} 12^{\prime} \mathrm{S}, 39^{\circ} 47^{\prime} \mathrm{W}, 1640$ m, 1 male (14 mm), MNRJ 19993.

Diagnosis: Carapace with rostrum overreaching scaphocerite, ventral margin with about ten teeth, dorsal margin with about 15 teeth; antennal spine absent; branchiostegal spine present, without distinct carina. Abdomen not dorsally carinate on all somites; somites 3 to 5 with posteromesial tooth, that of somite 3 distinctly strong. Tergum of abdominal somites 4 and 5 with markedly spinulose margin. Male pleopod 1 with endopod rounded, bilobed at tip, numerous densely articulated plumose setae on lateral margins, several hook setae at tip; male pleopod 2 with appendix masculina, slightly longer than appendix interna, rounded on distal portion (Cardoso \& Young, 2005).

Distribution: Western Atlantic: south of Greenland, Bermuda, Gulf of Mexico, Bahamas, Caribbean Sea, Brazil (Rio de Janeiro). Eastern Atlantic: Azores; west African coast, Nigeria, Congo, Angola. Indian and Pacific: Madagascar, Philippines, Indonesia, Hawaii.

Pandalidae Haworth, 1825

Heterocarpus A. Milne-Edwards, 1881

Heterocarpus A. Milne-Edwards, 1881: 8; Chace, 1985: 19; Holthuis, 1993: 268.

Diagnosis: Rostrum with dorsal and ventral teeth. Carapace without supraorbital spine, dorsally carinate nearly to posterior margin, with one or more lateral carinae. Pereopods 1-4 with epipods. Pereopod 2 unequal, left smaller that right (modified from Chace, 1985).

Heterocarpus inopinatus Tavares, 1999

Heterocarpus inopinatus Tavares, 1999: 673; Serejo et al., in press

Material examined: Oceanprof II: A-10, $22^{\circ} 11^{\prime} \mathrm{S}$, $39^{\circ} 51^{\prime} \mathrm{W}, 1157 \mathrm{~m}, 1$ female (13 mm), MNRJ 19989; A- $16,22^{\circ} 16^{\prime} \mathrm{S}, 39^{\circ} 53^{\prime} \mathrm{W}, 1056 \mathrm{~m}, 1$ female $(14 \mathrm{~mm})$, MNRJ 19996. 
Diagnosis: Rostrum shorter than carapace in adults (40 $\mathrm{mm})$, slightly longer than carapace in juveniles (24 $\mathrm{mm}$ ), upper margin with nine to 11 teeth, five teeth anterior to rostrum. Carapace with well developed postorbital and branchiostegal carinae, branchiostegal and antennal spines present. Abdominal somites 1 and 2 without dorsal carina; abdominal somites 3,4 and 5 carinate and with posterodorsal tooth. Maxilliped 3 with reduced exopod. Telson with four pairs of dorsolateral cuspidate setae and three pairs of distal setae, outer pair cuspidate short and small, median pair cuspidate long and stout and inner pair slender and simple (modified from Tavares, 1999).

Distribution: Western Atlantic: off the Brazilian coast (Espírito Santo, Rio de Janeiro).
Remarks: In Brazilian waters four species of Heterocarpus are recorded (Ramos-Porto \& Coelho, 1998; Tavares, 1999). Heterocarpus dorsalis Bate, 1888; $H$. ensifer A. Milne Edwards, 1881; $H$. inopinatus Tavares, 1999 and $H$. oryx A. Milne Edwards, 1881. All species of Heterocarpus have a well developed exopod on maxilliped 3, excepting $H$. oryx and $H$. reedii, with no exopod on maxilliped 3, and $H$. dorsalis and $H$. inopinatus that have a reduced exopod on maxilliped 3. Heterocarpus inopinatus can be distinguished from $H$. dorsalis by the dorsal carina on carapace unarmed on posterior one third of length in H. inopinatus (Fig. 3A) and unarmed on posterior two thirds in $H$. dorsalis.

A

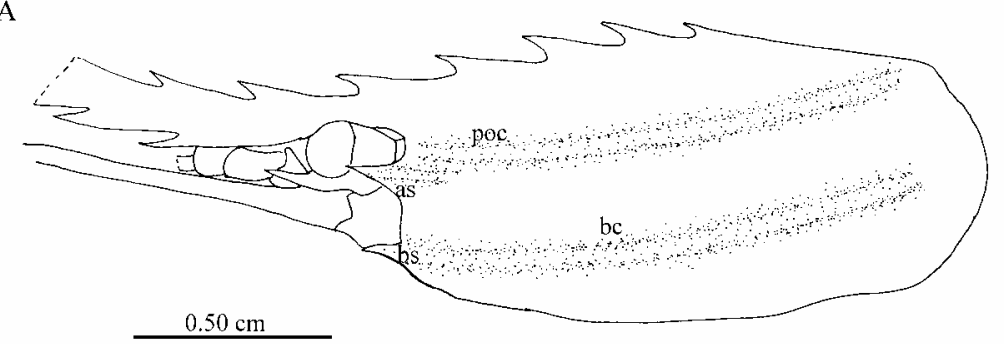

B

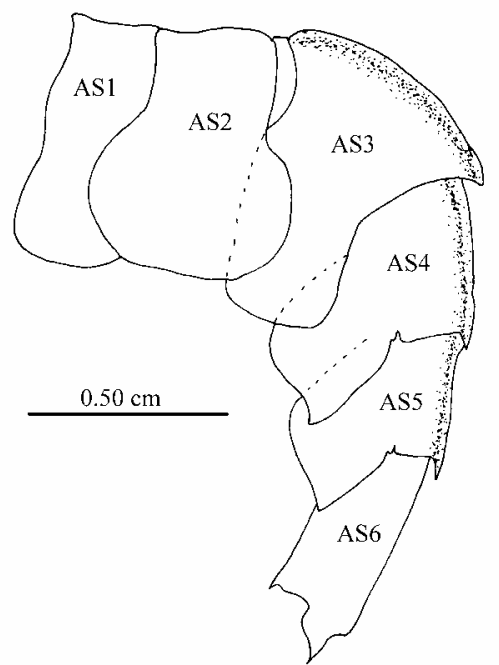

C

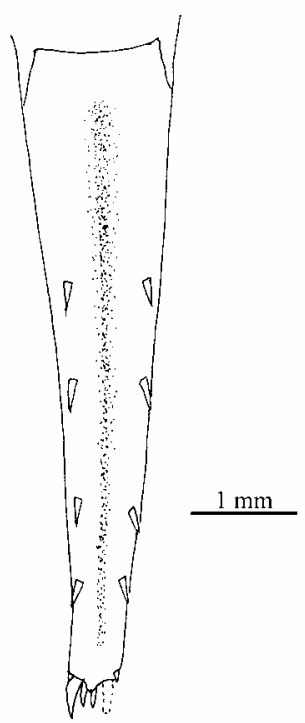

Fig. 3. Heterocarpus inopinatus Tavares, 1999, female (13mm), MNRJ 19989; (A) carapace lateral view; (B) abdominal somites 1-6, lateral view; (C) telson and uropods, dorsal view. (as) antennal spine; (AS) abdominal somites; (bc) brachiostegal carina; (bs) branchiostegal spine; (poc) postorbital carina). 
The material herein examined agrees with Tavares (1999) description in all features cited in the diagnosis (Fig. 3), except for the number of distal setae on telson, two in Tavares (1999) material and three in the present material (Fig. 3C). The material examined is certainly composed of two juveniles specimens what can justify the telson variation.

\section{AcKNOWLEDGMENTS}

We would like to acknowledge CENPES/PETROBRAS for providing the material examined and for the financial support.

\section{REFERENCES}

Alcock, A. 1901. A descriptive catalogue of the Indian deepsea Crustacea Decapoda Macrura and Anomala in the Indian Museum. Being a revised account of the deep-sea species collected by the Royal Indian Marine Survey Ship Investigator. p. 1-286.

Balss, H. 1925. Macrura der Deutschen Tiefsee-Expedition, 3: Natantia (Teil B). Wiss. Ergebn.Valdivia Expedition, 20(6): 217-315.

Barnard, K. H. 1950. Descriptive catalogue of South African Decapod Crustacea. Ann. S. Afr. Mus., 38:1-837.

Bate, C. S. 1888. Report on the Crustacea Macrura collected by the Challenger during the years 1873-76. Rept. Voy. Challenger, Zool., 24:1-942.

Boone, L. 1927. Crustacea from Tropical East American Seas. Scintific results of the First Oceanographic Expedition of the "Pawnee" 1925. Bull. Bingham oceanogr. Colln, 1(2):1-147.

Brullé, M. 1839. Crustacés. In: Webb \& Berthelot: Histoire naturelle des Iles Canaries, 2(2):15-18.

Calman, W. T. 1925. On Macrurous Decapod Crustacea collected in South African waters by the S. S. "Pickle". With a note on specimens of the genus Sergestes by H. J. Hansen. S. Afr. Fish. mar. Biol. Surv. Rep., 4(3):1-26.

Cardoso, I. A. (in press). New record of Meningodora vesca (smith, 1887) (Caridea, Oplophoridae) to the Southwestern Atlantic. Nauplius.

Cardoso, I. A. \& Young, P. S. 2005. Deep sea Oplophoridae (Crustacea, Caridea) from the southwestern Brazil. Zootaxa, 1031:1-74.

Caullery, M. 1896. Crustacés Schizopodes et Décapodes, In: Koehler, Résultats scientifiques de la campagne du Caudan dans le golfe ge Gascogne. Août-Septembre 1895. Ann. Univ. Lyon, 26:365-419.

Chace, F. A. 1936. Revision of the family Acathephyridae, with notes on a new family, Gomphonotidae. J. Wash. Acad. Sci., 26(1):24-31.

Chace, F. A. 1940. Plankton of the Bermuda Oceanographic expeditions, IX: The Bathypelagic Caridean Crustacea. Zoologica 25(2):117-209.

Chace, F. A. 1947. The deep-sea prawns of the family Oplophoridae in the Bingham Oceanographic collection. Bull. Bingham oceanogr. Colln,,11(1):1-51.

Chace, F. A. 1985. The Caridean Shrimps (Crustacea: Dercapoda) of the Albatross Philippine Expedition, 1907-1910, Part 3: families Thalassocarididae and Pandalidae. Smith. Contr. Zool., 411:1-143.
Chace, F. A. 1986. The Caridean shrimps (Crustacea: Decapoda) of the Albatross Philippine Expedition, 19071910, part 4: families Oplophoridae and Nematocarcinidae. Smith. Contr. Zool., 432:1-82.

Coutière, H. 1905. Note préliminaire sur les eucyphotes recueillis par S.A.S. le prince de Monaco à l'aide du filet à grande ouverture (campagnes de la "Princesse Alice" 1903-1904). Bull. Mus. Oceanogr. Monaco 48:1-35.

Crosnier, A. \& Forest, J. 1968. Note préliminaire sur les carides recueillis par l'Ombango au large du plateau continental, du Gabon à l'Angola (Crustacea Decapoda Natantia). Bull. Mus. Hist. nat., Paris, ser. 2, 39(6):11231147.

Crosnier, A. \& Forest, J. 1973. Les crevettes profondes de l'Atlantique oriental tropical. Faune trop., 19:1-409.

De Man, J. G. 1920. The Decapoda of the Siboga Expedition, IV: Families Pasiphaeidae, Stylodactilidae, Hoplophoridae, Nematocarcinidae, Thalassocaridae, Pandalidae, Psalidopodidae, Gnathophylidae, Processidae, Glyphocrangonidae, and Crangonidae. Siboga-Exped., 39a(3):1-138.

Faxon, W. 1893. Preliminary descriptions of new species of Crustacea. Reports on Dredging Operations off the West Coast of Central America to the Galapagos, to the West Coast of Mexico, and in the Gulf of California, in charge of Alexander Agassiz, carried on by the U. S. Fish Commission steamer "Albatross" during 1891. VI. Bull. Mus. comp. Zool. Harv., 24:149-220.

Faxon, W. 1895. The stalk-eyed Custacea. Reports on an Exploration off the West Coasts of Mexico, Central and South America, and off the Galapagos Islands, in Charge of Alexander Agassiz, by the U. S. Fish Commission steamer "Albatross", during 1891, Lieut. Commander Z. L. Tanner, U.S.N., commanding, XV. Mem. Mus. Comp. Zool. Harv., 18:1-292.

Garm, A. 2004. Revising the definition of the crustacean seta and setal classification systems based on examinations of the mouthpart setae of seven species of decapods. J. Linn. Soc. Lond., Zool., 142:233-252.

Holthuis, L. B. 1949. The Caridean Crustacea of the Canary Islands. Zoologisch. Meded., Leiden, 30:227-255.

Holthuis, L. B. 1971. The Atlantic shrimps of the Deep-Sea genus Glyphocrangon A. Milne-Edwards, 1881. Bull. mar. Sci., 21(1):267-373.

Holthuis, L. B. 1993. The Recent genera of the Caridean and Stenopodidean shrimps (Crustacea, Decapoda) with an appendix on the order Amphionidacea. Nationaal Natuurhistorisch Mus., Leiden. 328p.

Kemp, S. W. 1906. On the occurrence of the genus Acanthephyra in Deep Waters off the West coast of Ireland. Fish. Irel. Sci. Invest., 1:1-28.

Kemp, S. W. 1939. On Acanthephyra purpurea and its allies (Crustacea Decapoda: Hoplophoridae). Ann. Mag. nat. Hist., ser. 11, 4:568-579.

Kensley, B. 1972. Shrimps and prawns of Southern Africa. Cape Town: South African Museum. 65p.

Kensley, B. 1987. Deepwater Decapod Crustacea from eastern Australia (Penaeidea and Caridea). Rec. Austr. Mus., 39:263-331.

Komai, T. 2004. Deep-Sea shrimps of the genus Glyphocrangon A. Milne-Edwards, 1881 (Crustacea, Decapoda, Caridea, Glyphocrangonidae) from off Southeastern coast of Brazil collected during the REVIZEE Program. Arq. Mus. Nac., 62(1):31-44. 
Lenz, H. \& Strunck, K. 1914. Die dekapoden der Deutschen Südpolar-Expedition 1901-1903. I. Brachyuren und Macruren mit Ausschluss der Sergestiden. Deutsche Südpolar-Exped., 15(Zool. 7):257-345.

Martin, J. \& Davis, G. 2001. An updated classification of the Recent Crustacea. Nat. Hist. Mus. of Los Angeles County, Science Series, 39:1-124.

McLaughlin, P. A. 1980. Comparative morphology of recent Crustacea. San Francisco: W H. Freeman. 177p.

Milne-Edwards, A. 1881. Description de quelques Crustacés Macroures provenant des grandes profoundeurs de la mer des Antilles. Ann. Sci. nat., Zool., ser. 6, 11(4):1-16.

Milne-Edwards, A. 1883. Recueil de figures de Crustacés nouveaux ou peu connus. Paris: 3 p, 44 plates.

Milne Edwards, H. 1837. Histoire naturelle des Crustacés, comprenant l'anatomie, la physiologie et la classification de ces animaux, 2, 532p.

Moreira, C. 1901. Crustáceos do Brazil. Contribuição para o conhecimento da fauna brasileira. Arq. Mus. nac., 11:1151 .

Norman, A. M. 1886. Crustacea. Museum Normanianum, or a catalogue of the Invertebrata of Europe, and the Artic and North Atlantic oceans, which are contained in the collection of the Rev. Canon A. M. Norman, M. A., D. C. L., F.L.S. Ed. 1, Part 3:1-26.

Pequenat, L. H. 1970. Deep-sea Caridean shrimps with descriptions of six new species. Texas A \& M Univ.ocenaogr.Stud., I. Contributions on the biology of the Gulf of Mexico, 4:59-123.

Ramos-Porto, M. \& Coelho, P. 1998. Malacostraca. Eucarida. Caridea (Alpheoidea excluded). In: YOUNG, P.S., (ed). Catalogue of Crustacea of Brazil. Rio de Janeiro: Museu Nacional . p. 325-350 (Série Livros n. 6).

Rathbun, M. J. 1906. The Brachyura and Macrura of the Hawaiian Islands. Bull. U. S. Fish. Comm., 23(3):827930.

Riggio, G. 1895. Sul rinvenimento di nuovi Crostacei macruri nei mari della Sicilia. Natural Sicil., 14(12):244-249.

Roux, P. 1831. Mémoire sur la classification des Crustacés de la tribu des Salicoques. 39p.

Serejo, C. S; Young, P. S.†; Cardoso, I. C.; Tavares, C. Rodrigues, C. \& Almeida, T. C. (in press). Abundância, diversidade e zonação de Crustacea no talude da costa central do Brasil $\left(11^{\circ}-22^{\circ} \mathrm{S}\right)$ coletado pelo Programa REVIZEE Pesca - Score Central. In: COSTA, P.A.S.; Martins, A. S. \& Olavo, G. eds. Pesca e potenciais de exploração de recursos vivos da região central da Zona Econômica Exclusiva brasileira. Rio de Janeiro: Museu Nacional . (Série Livros n. 15.)
Sivertsen, E. \& Holthuis, L. B. 1956. Crustacea Decapoda (The Penaeidae and Stenopodidea excepted). Rep sci. Res. "Michael Sars" North Atlant. deep-sea Exped. 1910, 5(12):1-54.

Smith, S. I. 1882. Report on the Crustacea, Part I. Decapoda. Reports on the results of dredging, under the supervision of Alexander Agassiz, on the east coast of the United States, during the summer of 1880 , by the U.S. coast survey steamer "Blake", commander J. R. Bartlett, U.S.N., commanding. Bull. Mus. comp. Zool. Harv., 10:1-108.

Smith, S. I. 1884. Report on Decapod Crustacea of the Albatross dredgings off the east coast of the United States in 1883. Rep. U. S. Fish. Comm., 10:345-426.

Smith, S. I. 1886. The abyssal Decapod Crustacea of the Albatross dredgings in the North Atlantic. Ann. Mag. nat.. Hist., ser. 5, 17: 187-198.

Smith, S. I. 1887. Report on the Decapod Crustacea of the Albatross dredgings off the East coast of the United States, during the Summer and Autumn of 1884. Rep. U. S. Fish. Comm., 13:605-706.

Stebbing, T. R. 1905. South African Crustacea. Part III. Mar. Invest. S. Afr., 4:21-123.

Tavares, M. 1999. New species and new records of deepwater caridean shrimps from the South Atlantic Ocean (Crustacea Decapoda). Zoosystema, 21(4):671-677.

Watling, L. 1989. A classification system for crustacean setae based on the homology concept. In: Felgrnhauer, B. E.; Thistle, A. B. \& Watling, L. eds. Functional morphology of feeding and grooming in Crustacea. Crustacean Issues, A. A. Bakelma 6: 15-26.

Yokoya, Y. \& Shibata, K. 1965. On some shrimps from the Philippine Sea. Bull. Fac. Fish., Nagasaki, 18:1-6.

(Manuscript received 07 June 2006; revised 06 October 2006; accepted 26 October 2006) 